УДК $341.1 / 8$

DOI https://doi.org/10.32837/pyuv.v0i1(30).551

М.М. Ребкало

orcid.org/0000-0002-9633-5811

кандидат наук із державного управління, доцент кафедри теорї та історї держави і права, конституиійного права Акаделї Державної пенітенціарної служби

\title{
АСПЕКТИ ЕФЕКТИВНОСТІ ОХОРОНИ ЕКОЛОГІЇ ЧОРНОГО МОРЯ: МІЖНАРОДНО-ПРАВОВИЙ ОГЛЯД
}

Чорне море за різними офіційними джерелами має площу понад $420000 \mathrm{~km}^{2}$ із загальним об'є-

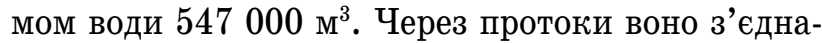
не з Азовським та Середземним морями. У ньому мешкає понад 2000 представників морської фауни і флори. Нафта і природний газ є основними копалинами, які видобуваються в Чорному морі. На його водних просторах здійснюється промислове рибальство, перевезення морських вантажів сухого та рідинного характеру тощо. Болгарія, Грузія, Росія, Румунія, Туреччина, Україна є прибережними державами цього морського регіону. Географічне розташування Чорного моря знижує природну здатність до самоочищення, і це робить його вкрай уразливим перед впливом різних негативних факторів. В останні роки в прибережних водах та у відкритому морі виявлена велика кількість морського сміття, особливого пластикового походження. Вчені-екологи вважають, що Чорне море є одним з екологічно небезпечних морських регіонів. На це вказує й доповідь Організації Об'єднаних Націй, де підтверджено зростання забруднення Чорного моря від суходільних джерел, річок, інтенсифікації використання морських суден, підвищення рівня інвазивних видів, які можуть нашкодити морській екосистемі тощо. У доповіді висловлена пропозиція вжити серйозних заходів, спрямованих на захист й оновлення середовища Чорного моря [1].

Така ситуація слугувала підвищенню уваги до Чорноморського басейну вчених, які представляють різні наукові галузі. Так, екологічні аспекти Чорного моря в останні роки досліджувались Б.Г. Александровим, Д.А. Барабанщиковим, Ю.П. Зайцевим, Г Г. Мінічевою, А.Ф. Сердюковою, на підставі чого було зроблено висновки про його незадовільний стан. Окремі сторони міжнародно-правового регулювання басейну Чорного моря розглядали М.В. Буроменський, А.С Джавадова, Л.Г. Заблецька, С.В. Ісакович, М.О. Медведєва, I.I. Каракаш, I.Е. Павлов. Такі науковці, як А.Й. Іванський, Н.В. Коржунова, А.С. Суржин, аналізували механізм міжнародно-правового регулювання процесами протидії негативному впливу на стан цього регіону. Загалом останнім часом спостерігається тенденція щодо зростання науко- вих досліджень у сфері охорони екології та природокористування Чорного моря. Питання ефективності чинного міжнародно-правового режиму протидії забрудненню Чорноморського басейну в сучасних умовах набуває певної актуальності.

Метою статті є дослідження міжнародноправового режиму збереження екології Чорного моря та аналіз аспектів підвищення ефективності цього процесу.

Історично Чорне море було зоною геополітичних інтересів прибережних держав та деяких країн Західної Свропи, а починаючи з другої половини XX ст. Чорноморський регіон став ще й об’єктом екологічної охорони, що детермінувало прийняття низки міжнародних актів та угод, за допомогою яких врегульовуються питання безпеки морського середовища. Кращому розумінню режиму збереження екології Чорного моря, на нашу думку, посприяє теоретико-правовий огляд міжнародних актів, які стосуються охорони Чорноморського басейну.

Конвенція про захист Чорного моря від забруднення є міжнародним документом, який підписали такі країни, як Болгарія, Грузія, Росія, Румунія, Туреччина, Україна, у 1992 р. в Бухаресті (Румунія), і присвячена спільним заходам щодо запобігання негативного впливу на морське середовище Чорного моря. У ній визначено такі джерела забруднення: від торгових, рибальських й інших суден та поховання небезпечних відходів або матеріалів внаслідок їх технічного використання; від стоків, що поступають із суходолів; від розробки континентального шельфу; від згубної дії наслідків надзвичайних ситуацій; від транскордонного переміщення небезпечних відходів тощо. Варто зауважити, що неабияка увага приділена збереженню живих морських ресурсів [2]. У цьому акті визначено певний механізм охорони Чорноморського басейну, компоненти якого містилися в Протоколі про захист морського середовища Чорного моря від забруднення 3 берегових джерел, Протоколі про співпрацю в боротьбі із забрудненням морського середовища Чорного моря нафтою та іншими шкідливими речовинами в аварійних ситуаціях, Протоколі про захист морського середовища Чорного моря від 
забруднення внаслідок скидів, Протоколі про збереження біорізноманіття та ландшафтів Чорного моря. Цей міжнародний документ передбачає співпрацю з наукових досліджень, спрямованих на розробку шляхів і засобів оцінки характеру й ступеня забруднення та його впливу на екологію морської води, виявлення найбільш забруднених районів, з'ясування факторів екологічної небезпеки та формування заходів щодо їх усунення. Країни-учасниці досягли консенсусу в необхідності реалізації системного моніторингу, що охоплює всі джерела негативного ураження Чорного моря. Одним із ключових наслідків конвенції було створення Комісії з захисту морського середовища Чорного моря від забруднення. В її компетенцію входить вивчення проблем та надання консультативної допомоги за такими напрямами: координація екологічної безпеки судноплавства; контроль забруднення з різних джерел; розробка єдиної методології управління береговою зоною; збереження біоресурсів у регіоні; екологічне регулювання риболовецької діяльності. Цьому органу підпорядковані Чорноморські регіональні центри активності, організовані на базі профільних національних установ. Отже, Бухарестська конвенція містить ключові засади формування сучасного механізму екологічної безпеки в Чорному морі.

У 1996 р. в м. Стамбул (Туреччина) відбулася Конференція по захисту навколишнього середовища Чорного моря, де представниками 25 національних парламентів було підписано відповідну декларацію. Підставою їі прийняття слугувало зростання рівня забруднення Чорноморського басейну від промислових і побутових джерел, від морських суден та атмосферного перенесення небезпечних елементів та ін. Одним iз значущих наслідків роботи конференції стало розширення кількості учасників, відповідальних за захист екології Чорного моря, до сімнадцяти держав. 3 метою недопущення катастрофічного стану Чорного моря в декларації передбачено конкретні заходи з протидії знищенню біологічного різноманіття цього регіону: 1) вдосконалити національне законодавство, яке має враховувати інтереси кожної країни-учасниці конференції та загальні вимоги щодо якості збереження навколишнього середовища Чорного моря; 2) прискорити комплексну реалізацію таких міжнародних угод, як Конвенція про захист Чорного моря від забруднення (1992р.), Міністерська декларація про захист Чорного моря (1993р.), Конвенція по запобіганню забруднення від суден (1978 р.), Конвенція Ради Європи про цивільну відповідальність за шкоду, завдану діями, небезпечними для навколишнього середовища (1993р.), Конвенція про збереження живої природи і природного місця існування в Європі (1979 р.); 3) відповідальність за заподіяну шкоду екології цього регіону має визначатися за принципом «забруднювач платить» та ін. Отже, Стамбульська декларація стала спільним проєктом держав Чорноморського басейну, який орієнтовано на впровадження сучасних екологічно безпечних виробничих технологій, модернізацію очисних споруд портів та прибережних міст, створення системи контролю за якістю морської води та ін.

Міжнародна конвенція про контроль суднового баластних вод й осадів та управління ними (2004 р.), на наш погляд, є важливим актом для правового регулювання екології Чорного моря. Причиною її прийняття стало те, що судна світового флоту є переносниками водних організмів, які містяться в баластних водах. Це, як показала практика, призвело до змін екосистем деяких морів і навіть окремих регіонів Світового океану і серйозних екологічних та економічних збитків. Наприклад, у 60-х рр. минулого століття через баластні води в Чорне море переселилася рапана (морський молюск), яка раніше ніколи тут не мешкала. Нині їі присутність загрожує знищенню колоній чорноморських мідій. Отже, згаданий міжнародний акт спрямований на забезпечення екологічної безпеки в районах скиду баластних вод, а також на необхідність проведення моніторингу за наслідками такої діяльності в межах морської території, яка знаходиться під юрисдикцією країн Чорноморського басейну [3].

Угода про збереження китоподібних Чорного моря, Середземного моря та суміжної акваторії Атлантичного океану покликана припинити знищення китоподібних і створення мережі спеціально охоронюваних територій для збереження цього виду. Держави Чорноморського басейну зобов'язалися вживати в рамках своєї юрисдикції такі заходи: законодавство країн-учасниць у цьому напрямі має враховувати положення згаданої угоди; управління процесом збереження китоподібних, охорону середовища їх проживання необхідно забезпечити на державному рівні; організація належного моніторингу районів мешкання китоподібних, збір та поширення інформації, навчання спеціалістів для діяльності у цій сфері; реагування на надзвичайні ситуації, що можуть призвести до загибелі цих тварин. Окрім того, положення угоди поширюються не тільки на всі водні простори, що знаходяться під суверенітетом прибережних країн, але й на судна, що плавають під прапором країн-учасників або зареєстровані на їхній території [4].

Окремо варто згадати про Бухарестську декларацію (2017 р.), в якій визначено низку заходів стосовно забезпечення стійкого рибальства та аквакультури в Чорному морі. У цьому акті запропоновано таке: створити належну систему співпраці між прибережними країнами задля раціональної експлуатації живих ресурсів; зміцнити багато- 
стороннє співробітництво з метою поліпшення стану маломасштабного рибальства; забезпечити належний розвиток аквакультури і пом'якшення загроз, що стоять перед морським середовищем; сприяти технічному співробітництву 3 питань, які стосуються сталого розвитку рибальства і аквакультури Чорного моря тощо [5, с. 348].

Отже, для реалізації завдань із збереження екології Чорного моря створено певний міжнародно-правовий режим. Тому вважаємо за доцільне проаналізувати його ефективність шляхом огляду та оцінки таких компонентів, як результативність співпраці прибережних та інших країн щодо збереження екології цього морського простору, доцільність та реальність спільних проєктів 3 екологічної безпеки Чорного моря, інтенсивність розвитку власного законодавства країн Чорноморського басейну стосовно охорони природного середовища цього морського регіону, системність та спрямованість екологічного моніторингу Чорного моря.

Діяльність із питань екологічної безпеки на двосторонньому та багатосторонньому рівнях країн чорноморського регіону, в тому числі й державами Європейського Союзу (далі - ЄС) набуває певної активізації. Так, у 2011 р. Європейський парламент затвердив резолюцію з Чорноморської стратегії. У документі вказується необхідність розробки пакету заходів зі створення екологічної інфраструктури в Чорному морі та звернуто увагу на необхідність зміцнення багатостороннього співробітництва в цьому напрямі. Окремо наголошено про потребу в інтеграції екологічних заходів на основі законодавства ЄС з охорони навколишнього середовища. В результаті країнами ЄС сформульовані шляхи співпраці з розв'язання екологічних проблем Чорного моря, в тому числі на двосторонньому рівні. Упродовж цього Україна уклала угоду з СС про фінансування спільної операційної програми прикордонного співробітництва «Басейн Чорного моря 2014-2020», котра сприяла ефективному і взаємовигідному співробітництву прикордонних регіонів України, в тому числі й захисту навколишнього середовища Чорного моря. Між Україною та Грузією підписано Меморандум про взаєморозуміння щодо співробітництва у сфеpi охорони навколишнього середовища Чорного моря та басейну Чорного моря (2017 р.). Сторони засвідчили, що підписання меморандуму - це початок великої спільної роботи в напрямі впровадження європейської екологічної політики в Чорному морі й координації дії у відновленні стану та збереження його природного середовища. Спеціальні угоди з питань охорони екології Чорного моря Україна має з Російською Федерацією та Румунією. У двосторонніх угодах між Болгарією та Туреччиною відбито досвід цих країн у сфері охорони природних ресурсів Чорного моря та сформульовані спільні заходи з протидії загрозам його забруднення антропогенними джерелами. Схожі угоди є між Туреччиною і Грузією, Болгарією та Румунією. Отже, рівень співпраці країн Чорноморського басейну та ЄС із питань екологічної безпеки здійснюється з певними темпами зростання, що дає змогу оптимістично подивитися не тільки на майбутне таких зносин, але й на результати їх спільної діяльності у процесі охорони природного середовища Чорного моря.

У практиці взаємовідносин прибережних країн ключове місце займає реалізація спільних проєктів та національних програм із захисту екології Чорного моря, що, на думку автора, має стати одним з ефективних аспектів діяльності прибережних країн. Прикладами цьому є Програма з охорони навколишнього середовища Чорного моря (1993 р.) та Стратегічний план дій для реабілітації і захисту Чорного моря (1996р.). Виявлення наземних джерел забруднення та порушень управління ресурсами стало одними з основних питань, виділених у Стратегічному плані. Варто зазначити, що в 2009 р. цей план був переглянутий усіма державами-членами, які підтвердили свою прихильність щодо захисту екосистеми Чорного моря. Для розв'язання екологічних проблем Чорного моря створена мережа національних і міжнародних центрів (6 міжнародних, 36 національних), що функціонують у рамках Чорноморської екологічної програми. Так, центр спеціального моніторингу та оцінки забруднень функціонує в Україні, а центр інтегрованого управління прибережною смугою - в Росії. Успішно працюють центри збереження біорізноманіття - в Грузії, екологічних аспектів судноплавства - в Болгарії, рибальства та інших живих ресурсів моря - в Румунії. $Є$ програми, які прийняті і реалізуються окремо кожною країно, деякі з них фінансуються країнами Західної Європи. Так, Туреччина та Росія мають по 1 програмі, Болгарія, Грузія - по 2, Румунія - 3, Україна - 4 програми [6]. Отже, країни Чорноморського басейну постійно проводять роботу зі створення певних спільних екологічних проєктів (програм), які спрямовані на стабілізацію екологічної ситуації в регіоні, їх об’єктами є найбільш небезпечні фактори впливу на морські простори та прибережну зону, що підтверджує їхню доцільність та реальність в реалізації.

Спостерігаються позитивні тенденції з розробки та вдосконалення національного законодавства у сфері управління екологічною безпекою Чорного моря. Так, Болгарія має закони стосовно морських територій, управління твердими відходами. Спеціальні закони про охорону навколишнього середовища є в арсеналі таких держав, як Грузія, Росія, Румунія, Туреччина, Україна. Крім того, Україна та Росія мають нормативні акти, які стосуються захисту територіального моря, внутрішніх вод, виключної економічної 
зони від дампінгового забруднення. У Грузії є закон про морські території. Румунія на законодавчому рівні врегулювала питання управління промисловими відходами та діяльністю морських портів (екологічні аспекти). Туреччина унормувала правила контролю за твердими й клінічними відходами та механізм відповідальності за забруднення морських територій, а також правила контролю за забрудненням морської води. У напрямі збереження екосистеми причорноморські країни мають такі нормативно-правові акти: про рибальство та сільське господарство (Болгарія); про тваринний світ (Грузія, Росія); про рибальство і аквакультуру (Румунія); про охорону морських біологічних ресурсів та державного контролю в цьому напрямі (Росія); про риболовство (Туреччина); про правила риболовства в басейні Чорного моря (Україна). Отже, чинні в країнах Чорноморського басейну закони та інші акти підтверджують позитивний вектор, який спрямований на формування власної нормативної бази, що, на думку автора, є дієвим фактором унормування на національному рівні питань збереження екології Чорного моря.

Формування належної системи екологічного моніторингу морського середовища, на нашу думку, має стати істотним заходом із підвищення ефективності протидії забрудненню Чорного моря. У його структуру входять органи загальнодержавного, регіонального та локального рівнів. Так, на національному рівні в Болгарії функціонує Міністерство навколишнього середовища й водних ресурсів, у Грузії - Міністерство охорони навколишнього середовища i природних ресурсів, у Росії - Міністерство природних ресурсів та екології, в Румунії - Міністерство навколишнього середовища і лісів, у Туреччині - Міністерство навколишнього середовища та містобудівництва, Міністерство охорони здоров'я, в Україні Міністерство енергетики та захисту навколишнього середовища. Серед об'єктів контролю варто назвати такі: джерела забруднення, які розташовані на узбережжі; скиди з кораблів; забруднення від діяльності з пошуку та видобування нафти, газу і будівельних матеріалів на морському шельфі; живі ресурси моря; стан морської води в зонах рекреаційного та оздоровчого водокористування й інші [7]. Необхідно зауважити, що моніторингу можуть підлягати й окремі об'єкти, як, наприклад, це здійснюють морські екологічні інспекції (Україна), але частіше цей процес реалізується комплексно. Він дає змогу проводити оцінку стану екосистеми Чорного моря протягом тривалого часу, спираючись на конкретну інформацію, яка отримується на різних об'єктах спостереження. Організація такої системи моніторингу дає змогу не тільки виявляти негативні фактори впливу, але й вивчати їх у динаміці і розробляти відповід- ні заходи збереження морської території та своєчасно запобігати проявам різного роду загроз. Отже, чинний екологічний моніторинг реалізується на рівні органів виконавчої влади системно, конкретно і комплексно та охоплює усі ключові об'єкти природного середовища Чорного моря,

Можна сформулювати такі висновки: 1) міждержавне співробітництво з охорони екології Чорного моря здійснюється як на двосторонньому, так багатосторонньому рівні у формі проведення конференцій та підписання міжнародних екологічних конвенцій, протоколів і угод, що загалом підтверджують позитивні тенденції такої співпраці; 2) формування стратегії у сфері охорони морського середовища та розробка й реалізація різних проєктів і програм проводиться як з урахуванням загальних загроз, так і в конкретному форматі, тобто з огляду на екологічні ризики, які виникають у кожній окремій прибережній державі і в яких інтегровані глобальні та регіональні ініціативи; 3) держави Чорноморського басейну розробляють (оновлюють) національне законодавство, націлене на протидію забрудненню Чорного моря з урахуванням вимог актів ООН і ЄС та власних інтересів, що ймовірніше призведе до формування єдиних екологічних стандартів і механізму їх реалізації серед прибережних країн; 4) структура та об'єкти екологічного моніторингу вказують на його системність та відповідність вимогам міжнародного морського права, здійснюється він як дискретно, так і комплексно, і забезпечується на рівні органів державної виконавчої влади країн Чорноморського регіону.

\section{Jimepamypa}

1. Стан морського середовища у Чорноморському регіоні: доповідь ООН від 03.11.2010 p. URL: http://pabsec.org/depo/documents/reports-andrecommendations/ru-repwsvgwg7ys.pdf (дата звернення: 12.03 .2020$)$.

2. Конвенція про захист Чорного моря від забруднення: міжнародний документ від 24.04.1992 р. Офiиійний вісник України. 2006. № 44. Ст. 2983.

3. Конвенція про контроль суднових баластних вод й осадів та управління ними : міжнародний документ від 13.02.2004 p. URL: https://zakon.rada.gov.ua/laws/ card/896_050 (дата звернення:18.03.2020).

4. Угода про збереження китоподібних Чорного моря, Середземного моря та суміжної акваторії Атлантичного океану : міжнародний документ від 24.11.1996 p. URL:https://ips.ligazakon.net/document/ view $/ \mathrm{mu} 96423 ? \mathrm{an}=2 \& \mathrm{ed}=1996 \_11 \_24$ (дата звернення:20.03.2020).

5. Бекяшаев Д.К. Международно-правовые проблемы управления рыболовством : монография. Москва : «Проспект», 2017. 512 с.

6. Приложение к Черноморской экологической программе о состоянии и управлении окружающей средой Чёрногоморя.URL:http://www.blacksea-commission.org/ Downloads/SAPIR2002/Russian/BSSAP_Annexes_ RU.pdf (дата звернення: 29.03.2020). 
7. Положення про морські екологічні інспекції : затверджено наказом Міністерства екології і природних ресурсів України від 04.11.2011 р. № 429. URL: https://zakon.rada.gov.ua/laws/show/z1348-11\#n4 (дата звернення: 07.04.2020).

\section{Анотація}

Ребкало М. М. Аспекти ефективності охорони екології Чорного моря: міжнародно-правовий огляд. Стаття.

Стаття присвячена міжнародно-правовому режиму збереження екології Чорного моря, який базується на положеннях міжнародних актів універсального та регіонального характеру. Об'єктами його впливу є джерела забруднення та їх об'єми, екосистема Чорного моря, охорона водних об'єктів морського й прибережного середовища від негативного техногенного впливу, підтримка розвитку господарської та іншої діяльності, яка відповідає встановленим вимогам з охорони навколишнього середовища і забезпечення екологічної безпеки, в тому числі із застосуванням доступних екологічно безпечних технологій, створення універсального контролю за природокористуванням у регіоні. У статті проаналізовано ефективність охорони Чорного моря в контексті оцінки таких показників: стан міжнародного співробітництва щодо збереження середовища цього регіону; доцільність та реальність програм екологічної безпеки Чорного моря; розвиток законодавства країн Чорноморського басейну з екологічної безпеки; відповідність моніторингу Чорного моря сучасним вимогам. Оцінено результати співпраці міжнародної спільноти з охорони екології Чорного моря, яка здійснюється шляхом підписання міжнародних актів як на багатосторонній, так і двосторонній основі. Встановлено, що в напрямі екологічної безпеки сформовано та узгоджено низку міжнародних проєктів, в яких інтегровані глобальні та регіональні ініціативи прибережних країн. Екологічне законодавство чорноморських країн втілюе положення міжнародних актів та власні інтереси, виходячи з ризиків та небезпек, які можуть їм загрожувати. Зауважено, що екологічний моніторинг загалом відповідає вимогам міжнародного морського права і реалізується на рівні органів державної виконавчої влади цих країн. Загалом міжнародне регулювання екологічної безпеки в основному сприяє ефективності охорони навколишнього середовища та створенню правових умов для раціонального використання природних ресурсів Чорного моря.
Ключові слова: Чорне море, прибережні країни, екологічна безпека, міжнародно-правовий режим, екологічне законодавство.

\section{Summary}

Rebkalo M. M. Aspects of Effectiveness of the Black Sea Ecological Protection: International and Legal Review. - Article.

The article addresses to the study of the international regime of the Black Sea ecological protection. The mechanism of international and legal regulation is based on the provisions of conventions, declarations, agreements of both universal and regional nature. Directions of impact on the ecology protection of the Black Sea are detailed, namely: identification of sources and the volume of pollution; conservation of the marine ecosystem; protection of marine and coastal area from negative technogenic influence; support for the development of economic and other activities that meet established requirements of environmental protection and environmental security, including the use of environmentally friendly technologies, creation of universal control over the use of environment in the region. The article focuses on the effectiveness of the Black Sea protection in the context of the following parameters assessing: state of international cooperation for the environment conservation of the region; feasibility and reality of the Black Sea environmental security programs; legislation development on ecological safety of the countries in the Black Sea basin; compliance of the Black Sea monitoring with the today's requirements. The article assesses the results of international cooperation on the Black Sea ecology protection, which was carried out at the level of international acts signing both on a multilateral and bilateral basis. A number of international projects are formed and agreed towards ecological safety, in which the coastal countries' global and regional initiatives are integrated. The environmental legislation of the Black Sea countries implements the provisions of international acts and their own interests, considering the risks and dangers that may threaten them.

The environmental monitoring in general meets the requirements of international maritime law and is implemented by the state executive authorities of these countries. In general, the regulation of ecological safety mainly contributes to the improvement of environmental protection and the creation of legal conditions for the rational use of the Black Sea's natural resources.

Key words: Black Sea, coastal countries, ecological safety, international and legal regime, environmental legislation. 